\title{
SEKOLAH SEBAGAI AGEN BINA DAMAI MELALUI RUANG KELAS
}

\author{
Nurhidayah dan Fikria Najitama \\ Institut Agama Islam Nahdlatul Ulama (IAINU) Kebumen \\ e-mail: hynur82@gmail.com
}

\begin{abstract}
ABSTRAK
Selama ini sekolah ibarat gunung emas, yang menjulang tinggi dan menyilaukan. Perasaan hebat dan berjasa menjadi nyanyian dunia pendidikan beserta para pelakunya. Namun siapa sangka, bila sekolah menjadi salah satu perintis kesenjangan sosial masyarakat yang terstruktur sebagaimana ungkapan Pierre Bourdieu. Para peserta didik yang haus akan pengetahuan dan dalam proses pencarian jatidiri pada akhirnya harus bertemu dengan sebuah konsep dan prosedur yang melegitimasi kesenjangan melalui kekerasan simbolik baik verbal maupun non verbal yang diterima di sekolah termasuk di dalam proses pembelajaran . Kekerasan yang mungkin disadari atau tidak sadari para pegiat pendidikan di dalamnya. Padahal fungsi sebuah pendidikan adalah untuk memberikan pengasuhan yang menanamkan nilai-nilai luhur kemanusiaan sebagai tugas Ke-Ilahian. Bahwa dengan pendidikan seseorang menjadi lebih percaya diri dengan apa yang ada pada dirinya dan disyukuri dengan meningkatkan kemampuan baiknya baik terhadap diri sendiri maupun orang lain. Seorang manusia yang cerdas yang memiliki kepekaan terhadap diri dan lingkungannnya. Sehingga mampu mengetahui permasalahan diri dan lingkungannya dan mencoba mencari solusi yang bersifat damai, bahwa peace is beautiful.
\end{abstract}

Kata Kunci: Sekolah, Pembelajaran, Agen Bina Damai 


\section{PENDAHULUAN}

Merasa paling adalah sebuah fenomena yang senantiasa akan ditemui seorang pendidik di dalam diri peserta didik ketika pembelajaran. Mulai dari merasa paling cantik, paling ganteng, paling alim, paling pintar, paling tajir bahkan merasa paling dalam konteks peyoratif seperti paling kurus, paling gendut, paling bodoh, paling miskin, paling jelek, paling malesan. Perasaan paling bisa muncul atau hadir dalam diri setiap siswa karena sebagai sebuah given/choice/bullying/ inself. Manakala given itu adalah given (pemberian) yang dari komunitas dalam sebuah kelas tersebut bersifat membangun tentu rasa ini perlu dikembangkan dan dapat menunjang pelajaran. Seperti given bahwa setiap peserta didik semua pintar, rajin,bisa, cantik atau ganteng akan berdampak memberi motivasi kepada siswa, membangkitkan minat belajar atau membangkitkan kemauan untuk rajin dan bisa. Namun demikian karena kelas adalah ruang akademis, maka alasan atau argumen yang diberikan hendaknya juga bersifat akademis.

Sebagai contoh untuk membuka suasana dalam sebuah pembelajaran yang penuh semangat dan gembira, mencoba menggunakan strategi pembelajaran PAIKEMI GEMBROT (Pembelajaran Aktif, Inovatif, Kreatif, Efektif, Islami, Gembira dan Berbobot), guru bisa menggunakan surat At-Tiin ayat 4 sebagai berikut:

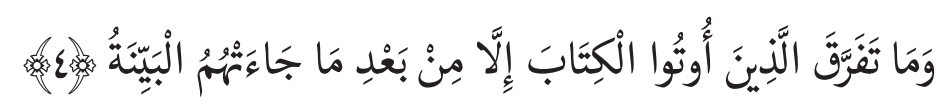

Artinya: Sesungguhnya Aku (Allah) telah menciptakan manusia dalam bentuk yang sempurna sempurnanya.

Ayat menunjukan bahwa Allah sudah menciptakan manusia dalam bentuk sebaik-baiknya dan sempurna. Bahwa setiap apa yang ada pada diri seseorang sudah sesuai porsinya, kebutuhannya, kepantasannya. Maka guru bisa memberikan given yang positif agar semua siswa merasa dalam arti positif sehingga bersyukur dan tidak melakukan bullying. Karena semua manusia ciptaan Allah yang maha sempurna. Semua pintar asal mau belajar dan berdoa. Semua bagus dan cantik kalau menjaga kebersihan. Kalimat dan argumentasi pendidik yang akademis tentu akan memberikan stimulus yang positif dan ketika peserta didik mendapat given yang bersifat positif mereka mempunyai argumen yang akademis sebagai defense (pertahanan diri) yang bersifat positif. Dampaknya ruang kelas mampu menjadi dinamisator dan filter dalam membangun toleransi yang berbasis ruang kelas. Kelas mampu menjadi agen bina damai melalui 
pendidik dan output-nya lahir peserta didik yang mampu menjadi pendamai pada komunitas terdekatnya.

Sebagaimana pengalaman penulis dalam sebuah diskusi perkuliahan, ketika di dalam diri mahasiswa "perasaan merasa paling" dialami oleh beberapa peserta didik bisa jadi merupakan sebuah given dari lingkungan sekolahnya atau lingkungan pergaulannya dimasa lalu seperti ungkapan "kami atau anak-anak kelas ini bodoh". Teman-teman di kelasnya adalah bodoh, maka penulis berusaha mendengarkan dan menampung keluh kesahnya terlebih dahulu. Kemudian setelah selesai karena mereka adalah peserta didik yang sudah dewasa maka penulis mengajak mereka menganalisis dengan menggunakan teori yang ada, melalui studi kasus. Salah satunya adalah teori Howard Gardner yang menyatakan tentang jenis kecerdasan penulis sajikan. Bahwa kecerdasan ada bermacam-macam. Kecerdasan secara logic, lingual, ritmik/musik, intrapersonal, interpersonal, visual, kinestetik atau spiritual. Tidak semua orang memiliki kecerdasan yang sama, ada yang cerdas dalam logic, ada juga yang cerdas secara kinestetik, ada yang cerdas secara ritmik/musik, ada yang cerdas interpersonal, ada juga yang cerdas intrapersonal dan berbagai kecerdasan lainnya. Ketika seseorang memiliki kemampuan yang lebih sedikit dalam memahami suatu konsep bila harus dijelaskan secara verbal bukan berarti dia tidak memiliki kecerdasan, karena mungkin dia mudah hafal ketika memahami sebuah konsep dengan melalui musik atau secara visual. Ada juga yang biasa saja namun dia sangat dicintai semua siswa dikelasnya karena sikap penolong dan ramahnya. Pada akhir diskusi rasa puas dan percaya diri, dengan ditandai rasa damai pada dirinya dan orang lain muncul pada mahasiswa di kelas tersebut.

Kecerdasan setiap orang berbeda antar satu individu dengan individu lain, maka pengakuan dan penghargaan kecerdasan terhadap orang lain adalah sebuah keniscayaan. setiap individu unik dan berbeda maka tidak bisa dituntut untuk sama. Oleh karenanya di dalam sebuah pembelajaran di sebuah kelas pemahaman dan penguasaan guru terhadap peserta didiknya adalah sebuah keharusan. Kelas bisa menjadi agen bina damai ditingkat grassroot, manakala kelas sukses membangun dan membina damai dalam diri siswa terhadap dirinya, kondisinya, maka ia akan mampu membentuk komunitas/masyarakat yang damai dan cinta damai. Kesuksesan sangat bergantung pada kreatifitas dan inovasi pendidik dalam pembelajaran. 
Di zaman now yang mana akses teknologi sudah melampaui batas teritorial dan geografis adalah sebuah tantangan yang tidak mudah bagi dunia pendidikan khususnya pendidik. Manakala pendidik hanya terpikat dan terjerumus pada budaya materialisme yang hanya berfokus pada penyampaian materi menjadikan siswa atau peserta didik yang masih dalam tahap pembentukan citra diri menjadi tidak kokoh secara kepribadian ${ }^{1}$ bahkan mandeg.

\section{KELAS SEBAGAI AGEN BINA DAMAI}

Mengkaji bina-damai yang secara teminologis adalah frase yang jika diterjemahkan dalam bahasa teori pendekatan perdamaian disebut sebagai "peace building". Peace (damai) diartikan sebagai kondisi dimana tidak ada lagi peperangan (no war) atau perkelahian (nofighting). Namun secara praksis peace bukan sekedar tidak adanya peperangan, tapi konflik dalam arti luas. Sedangkan building adalah proses atau kepentingan membangun sesuatu, yang dalam bahasaIndonesia baku disebut "bina" ${ }^{2}$. Louis Kriesberg mengembangkan teori bina-damai secara komprehensif. Konflik dipandangnya sebagai sesuatu yang natural ada dalam hidup manusia, konflik bisa berakhir secara destruktif atau konstruktif. Menurutnya ada tiga mekanisme dengan apa konflik bisa diselesaikan secara damai dan menjadi sesuatu yang konstruktif, yaitu melalui: (1) mekanisme internal kelompok;(2) mekanisme antar kelompok; dan (3) mekanisme diluarnya (ekstra). ${ }^{3}$

Apabila meletakkan teori ini dalam konteks konflik pada proses tumbuh kembang peserta didik, maka konflik bisa diartikan dalam ranah in self atau out self peserta didik maka hal ini bisa melibatkan pendidik untuk mengelola dan melakukan bina damai melalui proses pembelajaran di ruang-ruang kelas. Kelas yang berfungsi sebagai ruang sosial kedua bagi peserta didik setelah rumah atau keluarga.

Oleh karena itu kelas yang ideal hendaknya mampu menjadi fasilitator atau agen dalam bina damai sebuah masyarakat. Karena kelas adalah miniatur komunitas masyarakat dalam arti sempit. Setiap sekolah/madrasah mempunyai

1 Hasil riset penulis tentang kematangan psikologis sebagai dampak proses pembelajaran tahun 2016-2017 terhadap 500 responden melalui FGD. Lihat, Nurhidayah, Kematangan Psikologis Sebagai Dampak Proses Pembelajaran Tahun 2016-2017. Penelitian. Tidak diterbitkan.

2 Rahman Mantu, "Bina Damai dalam Komunitas Pesantren: Sebuah Upaya CounterRadikalisme",dalam jurnal Walisongo, Volume 23, Nomor 1, Mei 2015.

3 Ibid. 
kelas yang lebih dari satu.Manakala kelas mampu menjadi dinamisator dan fasilitator kehidupan harmonis antar inter-individu dan atau intra-individu satu dengan individu lain, maka komunitas/masyarakat dimana para individu yang telah memperoleh ruang dan training damai di sekolah/madrasahnya melalui kelas-kelas yang ramah dan damai akan membentuk sebuah masyarakat/ komunitas yang damai. Selanjutnya komunitas/masyarakat masyarakat yang cinta damai akan mampu mewarnai dan membentuk wilayah yang masyarakatnya damai dan suka damai, puncaknya akan terbentuk masyarakat sebuah negara dan bangsa yang cinta damai dan suka mengusahakan perdamaian didalamnya. Impian yang dewasa ini sangat dirindukan banyak orang dan bangsa. Sebuah kondisi dimana setiap anggota masyarakat mampu dan mau menerima anggota masyarakat lain tanpa prasangka. Kesadaran bahwa mereka sama, sama-sama manusia dan mempunyai hak dan kewajiban yang sama sebagai manusia. Bahwa setiap individu punya hak yang terbatasi hak orang lain, mempunyai kewajiban yang sama untuk menghargai kewajiban orang lain.

Kelas bagi peserta didik bukan hanya berfungsi sebagai ruang publik, dimana ia hanya bertemu dan berkumpul dengan orang lain hanya untuk mengambil dan menerima transfer pengetahuan baru, konsep baru. Lebih dari itu kelas adalah ruang-ruang privat seorang peserta didik dalam membentuk dan mengetahui siapa dirinya, apa hak dan kewajibannya dengan bantuan seorang pendidik melalui proses pembelajaran. Kelas menjadi laboratorium mini setiap individu yang menjadi anggota dalam kelas tersebut untuk mengenali dan menguji dirinya. Maka strategi dan pendekatan guru/dosen atau pendidik hendaknya mampu memberi ruang bagi peserta didik untuk bereksperimen. Tentu saja sebelum melakukan eksperimen tersebut seorang pendidik sebagai fasilitator memberikan sebuah alat uji, metode, langkah atau urutan prosedur yang sesuai. Oleh karena pembelajaran yang menggunakan student approach bisa menjadi pilihan. Sehingga peserta didik mengetahui dan menemukan konsep dirinya melalui pengalaman. Akhirnya peserta didik memiliki kemampuan dan kemauan damai. Minimal untuk berdamai dengan dirinya, orang lain dan komunitasnya ${ }^{4}$. Menerapkan kelas sebagai agen damai tentu bukan hal mudah, tetapi bukan pula menjadi hal yang sulit atau tak mungkin. Oleh karenanya kita perlu mengenal 12 konsep nilai dasar perdamaian pada manusia, seperti yang disusun oleh peace education. ${ }^{5}$

$4 \quad$ Lebih lanjut baca, Mustamir Pedak, Metode Supernol Menaklukan Stress, (Jakarta: Hikmah, 2009), hlm, 219.

5 Sebuah organisasi perintis perdamaian yang terdiri dari berbagai elemen masyarakat dari berbagai bangsa dan negara dan berpusat di Bandung. 
Dalam 12 konsep nilai dasar perdamaian peace education hal terpenting yang harus dikenalkan dan didamaikan oleh peserta didik adalah damai dengan diri sendiri (Accepting ourself). Point pertama ini menuntut seorang pendidik mampu mengarahkan peserta didik dengan dirinya baik secara fisik maupun non fisik. Mampu menerima dan mensyukuri apa yang Tuhan berikan padanya. Penekanan bahwa dia cerdas dan bagus, dengan mengenalkan berbagai kecedasan yang mungkin sesuai dengan karakter peserta didik. Adapun secara fisik, pendidik hendaknya mengarahkan warna kulit seseorang adalah warna terbaik yang Allah berikan. Banyak keindahan dan kekuatan disana. Bahwa warna kulit terbaik adalah ketika sang pemilik berakhlak baik entah dia berkulit coklat, hitam atau putih, tinggi atau pendek, kurus atau gemuk, kaya atau miskin. Kedua, bahwa menghapus prasangka (No suspicion, no prejudice) adalah sebuah langkah awal untuk memulai sebuah kehidupan, persahabatan dan perdamaian. Ketiga Keragaman etnik (ethnic diversity), point ini menekankan kepada pendidik untuk mengenalkan, mengarahkan kesadaran peserta didik bahwa setiap individu unik dan berbeda dan terbagi dalam etnis/suku/ras yang berbeda namun demikian memiliki keinginan yang sama hidup damai maka berdamai dengan saling menghargai dan menghormati adalah sebuah kebajikan.

Keempat adalah pengenalan beragamnya agama yang pada akhirnya melahirkan perbedaan agama di sebuah masyarakat. Agama adalah masalah rasa dan keyakinan, maka tidak boleh dipaksakan. Selanjutnya kelima adalah perbedaan gender ${ }^{6}$. Perdamaian adalah harapan setiap orang tanpa memilih laki-laki atau perempuan, tua atau muda, besar atau kecil semua suka damai, oleh karena itu perdamaian ada karena diciptakan untuk semua. Perbedaan status sosial, perbedaan kelompok, cara merayakan sebuah perayaan, cara memandang konflik adalah beberapa faktor yang kadang sering menimbulkan konflik. Pengetahuan dan kesadaran pentingnya untuk memahami perbedaan dan mendorong keberanian untuk meminta maaf adalah sebuah tugas pendidik dalam ruang kelas yang hendaknya diaplikasikan. Sehingga model pembelajaran di kelas dipilih dan dipertimbangkan berdasar problem dan karakter peserta didik, usia peserta didik. Dengan demikian nilai-nilai damai diterima oleh peserta didik dengan proses menemukan dan kesadaran. Model cooperative learning/ teaching atau active teaching yang membagi siswa dalam kelompok-kelompok heterogen terlihat sangat membantu pendidik dalam mengasah dan memupuk bina damai dalam diri peserta didik maupun antar peserta didik.

6 Gender dalam konteks sosial budaya. 
Cooperative learning/teaching yang terbagi dalam tim-tim tertentu sesuai tipe model yang dipakai seorang pendidik, seperti JigSaw, TGT, dan lainnya akan membantu peserta didik untuk mengasah kepekaaan, tanggung jawab bersama, hormat menghormati, kerjasama, kompak dan tepo sliro. Berdamai dengan dirinya dan anggota tim lainnya ketika salah satu atau anggota mampu dan atau belum mampu melaksanakan kewajiban, tolong menolong, saling menyemangati, legowo atau menerima dengan hati lapang dan senang baik kalah atau menang, bisa atau tidak namun tetap bersemangat untuk bisa dan bertanggungjawab terhadap tugasnya adalah kelebihan-kelebihan dalam model pembelajaran ini. Oleh karenanya dibutuh kepekaan dan pengetahuan luas pendidik terhadap karakteristik dan kekhasan dari peserta didiknya, psikologi perkembangannya. Berikut di bawah ini 12 konsep nilai dasar perdamaian yang diadopsi dari peace education untuk perdamaian:

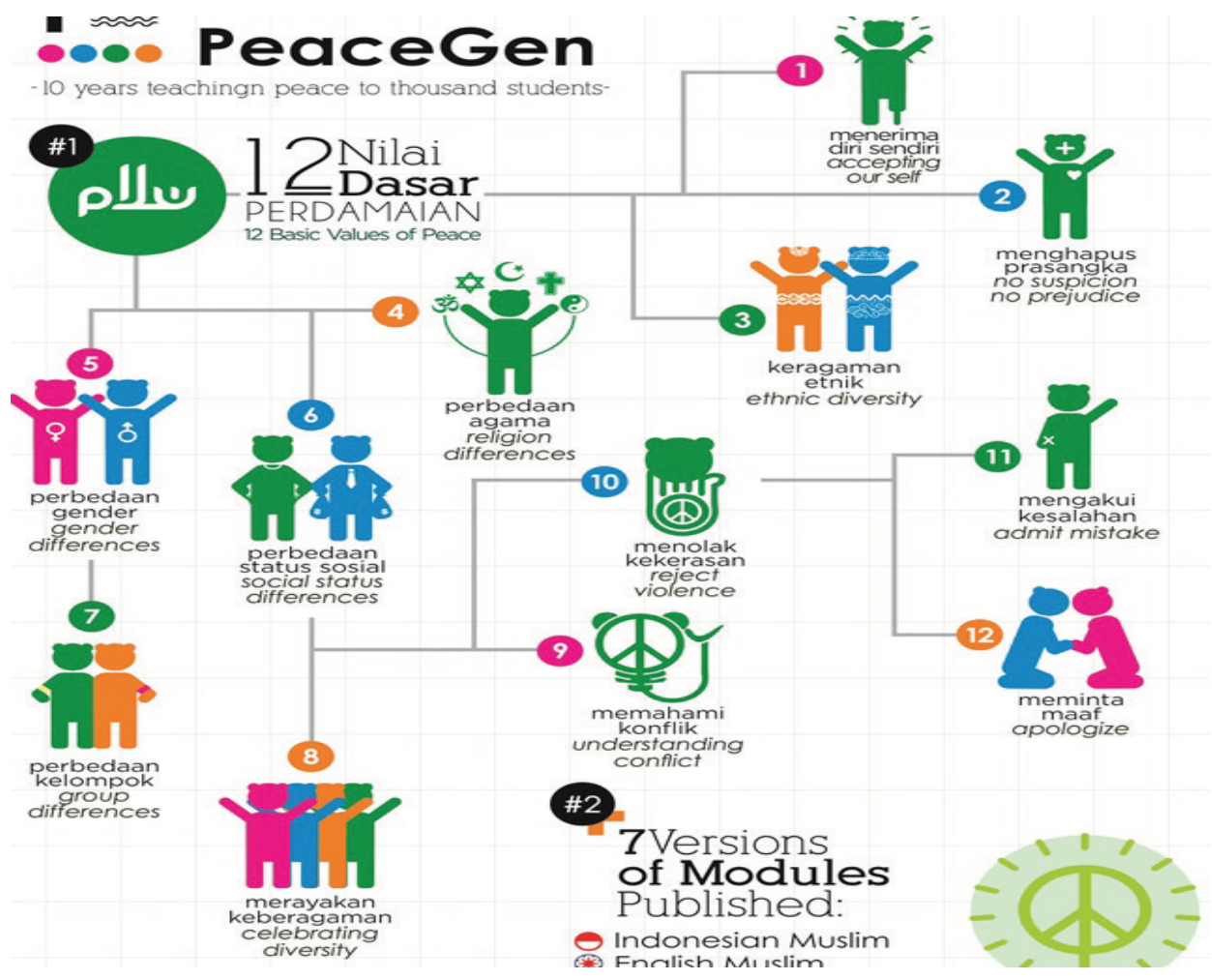

Gambar 1.

12 Nilai Dasar Perdamaian ${ }^{7}$

$\overline{7}$ Www. Peace-generation.org. 10 Tahun Peace Generation. Diunduh tanggal 10 Januari 2018. 
Sekarang mari kita bandingkan dengan kondisi kebhinekaan kita Indonesia. Sejauhmana keberhasilan kita dalam mengenalkan dan menanamkan rasa kebhinekaan dan kesadaran multikultur bangsa Indonesia akan menjadi sebuah kenyataan, ketika ruang kelas-ruang kelas di sekolah/madrasah menjadikan kelas sebagai agen of peace education. Namun demikian keberhasilannya juga akan sangat tergantung kepada kesadaran para pendidik di sekolah-sekolah dan madrasah di sekitar kita. Prinsip mulailah dari diri sendiri, oleh kita sendiri mungkin perlu diterapkan dalam menerapkan sekolah/madrasah sebagai agen dalam bina damai yang mulai terpotong-potong oleh egosentrisme dan kesalahan logika.

Peran kelas dalam bina damai bagi peserta didik, menjadikan para pelajar atau pemuda yang masih dalam usia pancaroba ${ }^{8}$ bisa lebih selektif dalam memilah dan memilih keputusan dan informasi sehingga tidak terjebak pada radikalisme baik atas nama agama, kelompok, suku atau etnis ${ }^{9}$ dan lain sebagainya. Oleh karena ketepatan seorang pendidik dalam memilih pendekatan model dan metode dalam pembelajaran di kelas sangat mempengaruhi efektifitas kelas dalam menjalankan fungsinya sebagai agen bina damai. sebuah pertanyaan yang bisa menguji apakah kelas Anda sudah menjadi agen bina damai adalah "Apakah jawaban peserta didik Anda sudah mampu menuliskan dan mendeklarasikan diri dalam konteks positif bahwa "AKU BANGGA DENGAN DIRIKU". Bila pertanyaan atau pernyataan itu hadir dalam peserta didik maka Anda patut diberikan reward karena mampu menjadikan kelas sebagai ruang bina damai di tingkat sekolah/madrasah. Berikut adalah peta kecerdasan bila pendidik akan menggunakan simulasi dalam tim sesuai tipe kecerdasan peserta didik menurut Lou Russel:

8 Dalam Nurhidayah, "Dekonstruksi Fanatisme Keagamaan Berbasis Sekolah: Alternatif Pendekatan Deradikalisasi Gerakan Keagamaan di Tingkat Usia Pelajar Muslim", dalam Jurnal An-Nidzam. Vol. 1, No. 2, Tahun 2014.

9 Hasil penelitian penulis tahun 2017 tentang keterlibatan oknum pelajar dalam aksi penjarahan etnis Thionghoa 1998 di Kebumen yang ikut-ikutan kerumunan orang yang menjarah. 


\begin{tabular}{|l|l|}
\hline Kecerdasan & Aspek simulasi \\
\hline Interpersonal & Simulasi dilakukan dalam sebuah tim \\
\hline Linguistik/verbal & Simulasi perlu aktivitas bicara dan mendengar \\
\hline Spacial/visual & $\begin{array}{l}\text { Simulasi perlu penginterprestasian dan cetak biru } \\
\text { dan penciptaan model visual }\end{array}$ \\
\hline Musikal & Musik instrumental dan tenang selama simulasi \\
\hline Logis/matematis & Perencanaan perlu pendekatan langkah demi langkah \\
\hline Intrapersonal & $\begin{array}{l}\text { Tiap individu harus memberikan bagiannya untuk } \\
\text { kesuksesan tim }\end{array}$ \\
\hline Jasmaniah/kinestetik & Pembangunan jembatan perlu gerak fisik \\
\hline Emosional & Persaingan dalam simulasi memberi kegembiraan \\
\hline Naturalis & Lemah, meski simulasi dilakukan di luar ruangan \\
\hline Eksistensial & $\begin{array}{l}\text { Individu perlu kejelasan mengenai perannya untuk } \\
\text { kesuksesan tim }\end{array}$ \\
\hline
\end{tabular}

Berdasar peta kecerdasan ini dituntut pemahaman dan ketelitian seorang pendidik terhadap kekhasan masing-masing individu peserta didik di kelasnya. Sebuah ungkapan menarik Mahfud ${ }^{10}$ bahwa guru kekinian bukan saatnya lagi berperan sebagai bankir (gudang) ilmu dan nilai yang tiap saat siap diberikan ke peserta didik. Akan tetapi guru atau pendidik yang mampu berperan sebagai partner, teman dialog dalam menciptakan situasi beriptek dan bersosial ${ }^{11}$. Dalam arti menguasai iptek secara invidu dan mampu menjadikan iptek tersebut menjadi pribadi yang baik terhadap diri dan orang lain. Mendidik seseorang yang mampu menghargai dan menghormati diri dan orang lain. Guru hendaknya mampu menjadikan pembelajaran di kelas disusun sebagai simulasi kehidupan nyata sehingga peserta didik berpengalaman hidup sebagai warga masyarakatnya. Oleh karenanya proses pembelajaran, materi dan media lebih bersifat kontekstual dengan pengalaman siswa.

10 Mahfudz, Pendidikan Multikultural, (Yogyakarta: Pustaka Pelajar, 2011), hlm. 271.

11 Q.S Al-'Araf ayat 56 "Dan Janganlah kamu membuat kerusakandi bumi sesudah (Allah) memperbaikinya, dan berdoalah kepada-Nya dengan rasa takut (tidak akan diterima) dan harapan (akan dikabulkan). Sesungguhnya rahmat allah amat dekat kepada orang-orang yang berbuat baik". 


\section{PRINSIP, KONSEP DAN APLIKASI PEMBELAJARAN DI KELAS SEBAGAI MEDIA BINA DAMAI.}

Prinsip Dorothy Low Notle ${ }^{12}$ di bawah ini perlu direnungkan dalam mengelola sebuah pembelajaran di kelas baik sekolah/madrasah. Terlebih dalam ruang-ruang kelas. Ungkapan bahwa:

Jika anak dibesarkan dengan celaan, ia belajar memaki

Jika anak dibesarkan dengan permusuhan maka ia akan belajar berkelahi

jika anak dibesarkan dengan ketakutan, ia belajar untuk gelisah

Jika anak dibesarkan dengan penghinaan, ia akan belajar menyesali diri

Jika anak dibesarkan dengan cemoohan, ia akan belajar rendah diri

Jika anak dibesarkan dengan dipermalukan, ia belajar merasa bersalah

Ungkapan Dorothy di atas memberikan prinsip-prinsip pada pendidik bahwa begitu penting arti dan urgennya sebuah ungkapan, tindakan dan persepsi serta pemikiran seorang pendidik atau orangtua bagi tumbuh kembang baik fisik dan mental anak. Sehingga mata pelajaran apapun yang disampaikan seorang pendidik di kelas hendaknya memberikan sebuah pengalaman yang dibutuhkan dalam hidupnya baik sekarang, dan yang akan datang yang bersifat positif dengan belajar dari kesalahan masa lalu. Seperangkat pengetahuan tentang diri dan lingkungannya dengan berprinsip pada perkembaangan dan pertumbuhan anak itu sendiri. Dengan catatan bahwa meskipun pengetahuan baru yang disampaikan disesuaikan dengan konteks kekinian namun tanpa melupakan local genius atau local wisdommasyarakat dimana peserta didik itu tinggal atau berasal. Sehingga dalam istilah budaya, guru atau pendidik diharapkan tidak antem kromo. Oleh karena itu mata pelajaran yang disampaikan akan menekankan pada beberapa ketrampilan yang hendaknya menyertai dalam pembelajarannya. Berikut tiga (3) ketrampilan dalam pembelajaran yang ideal, yaitu:

1. Ketrampilan berpikir

Ketrampilan berpikir yang dimaksud menuntut siswa mampu menggunakan konsep dan membuat generalisasi dalam sesuai usianya yang masih membuat konsep dan generalisasi merupakan ketrampilan tingkat tinggi, adapun ketrampilan tingkat rendahnya adalah seperti

12 Ibid 
menggambarkan, menjelaskan, menggolongkan, membandingkan, meramalkan, melihat kausalitas atau hubungan sebab akibat. Studi kasus mungkin metode yang bisa dipakai dalam membangun sensifitas bina damai peserta didik baik in atau out self

2. Ketrampilan teknis

Ketrampilan teknis dalam hal ini adalah ketrampilan menggunakan data dan media,alat bantu dalam mencari dan menyajikan informasi. Contoh membuat tabel, diagram, peta, kliping, denah, gambar, melakukan wawancara, survey, pengamatan, membuat model, mencatat hal penting, membuat laporan, membacakan laporan.

3. Ketrampilan sosial

Dalam hal ini ketrampilan sosial yang dimaksud adalah ketrampilan untuk berinteraksi dalam kelompok, kelas, dan lain sebagainya untuk bisa hidup dan bekerjasama secara harmonis. ${ }^{13}$

Berprinsip pada rambu-rambu di atas bahwa pembelajaran di kelas dirancang sebagai agen bina damai maka mungkin lebih tepat bila menempatkan proses pembelajaran sebagai sebuah proses pengasuhan yang bermakna ${ }^{14}$. Pengasuhan yang menurut Shochib ${ }^{15}$ bermakna upaya orang tua mendekatkan diri kepada anak-anaknya dalam rangka memasukkan nilai-nilai positif kepada anak-anaknya. Hal ini berarti bahwa manakala pendidik mampu menempatkan anak didik selayaknya anak sendiri dengan pendekatan pendekatan hati ke hati. Seorang tua yang baik harus tahu ilmu dan anaknya bila ingin dekat dengan anak dan anaknya menjadi baik. Oleh karena itu. Pengasuhan bertujuan menanamkan nilai-nilai positif dan luhur, oleh karenanya diperlukan cara dan prosedur yang baik.

Proses pengasuhan dalam ranah pembelajaran di kelas, seorang pendidik akan menemukan fakta-fakta yang bersifat semu. Tingkah laku semu, artinya bahwa peserta didik yang di hadapannya adalah pribadi-pribadi yang sudah mendapatkan pola asuh yang berbeda dan apa yang tampak mungkin akan berbeda dengan apa yang dipikirkan dan bakatnya. ${ }^{16}$ Karena menurut Daniel

13 Humaisyi, M. Syafiq, Pengantar IPS, (Ponorogo: STAIN Press, 2012), hlm. 33-41.

14 Dalam Azzam Syukur R, "Attachment Parenting dalam Perspektif Psikologi Pendidikan Islam" dalam Jurnal An-Nidzam, Vol 1, No 2, 2014. hlm. 186.

15 Ibid.

16 Menyadur pemikiran Pierre Bourdieu sosiolog Perancis dalam Distinction (1994) yang dikutip oleh Ken Plummer dalam Kekerasan Simbolik di Sekolah: Sebuah Ide Sosiologi Pendidikan 
Goleman ${ }^{17}$ bahwa kita memang tercipta untuk berhubungan. Dijelaskan bahwa ilmu saraf telah menemukan bahwa rancangan otak sendiri membuat otak itu suka bergaul. Akibatnya otak mau tak mau tertarik ke dalam kaitan antara otak dengan otak setiap saat kita berhubungan dengan orang lain. Jembatan saraf inilah yang memungkinkan setiap orang mempengaruhi otak, tubuh dan siapa saja yang berinteraksi dengannya. Dan begitu pula sebaliknya. Semakin kuat secara emosi kit tersambung dengan seseorang, begitu pula sebaliknya kekuatan timbal baliknya.Perasaan tersebut mengontrol hormon yang mengatur sistem biologis.

Dengan demikian dalam sebuah pembelajaran prinsip utama seorang pendidik adalah bahwa ia harus bisa menjadi ibu, orangtua, mitra terbaik dan terdekat bagi peserta didik. Pembelajaran adalah sebuah interaksi yang ditandai hubungan timbal balik antar pendidik dan peserta didik. Sekolah/Madrasah harus bisa menjadikan ruang-ruang kelas sebagai laboratorium mini kehidupan sosial siswa yang menyenangkan, damai sehingga mampu memberika memori kolektif dimasa yang akan datang. Masa dimana siswa atau peserta didik masuk ke dalam wilayah di luar kelas atau sekolah. Wilayah yang sebenarnya yaitu masyarakat yang terdiri dari dari berbagai individu-individu yang unik, khas yang memiliki pengetahuan dan pengalaman pendidikan yang berbeda.

Pembelajaran di kelas yang menyenangkan dan kreatif (how to learn) yang melibatkan sisi kemanusiaan siswa yang suka berkelompok, memberikan peluang kepada peserta didik untuk mengetahui konsep diri (how to Know) dan memberi ruang untuk menjadi (how to be). Pengalaman belajar di kelas adalah pedoman, sketsa dan cermin bagiamana siswa akan berhubungan dengan individu lain/orang lain di lingkungannya ( how to live together). Bilamana sekolah memberikan basic pengalaman melalui pengasuhan yang sistematis dan mampu menjadi agen bina damai maka siswa akan menjadi masyarakat yang baik kelak ketika tiba saatnya.

Pierre Bourdieu oleh Nanang Martono tersurat bahwa dalam meneliti kesenjangan sosial dalam kehidupan masyarakat, Bourdieu mengklaim bahwa kebudayaan dan bacaan yang kita baca dan alami, memainkan peran utama dalam membentuk kelas sosial dan stratifikasi sosial sebagaimana uang dalam ekonomi. Sekolah dan dan dunia pendidikan harus dilihat sebagai salah satu institusi utama yang turut membentuk dan menghasilkan kesenjangan tersebut. 
Karakter dan kepribadian yang matang menjadi out put sebuah kelas yang damai yang terbaik ditandai dengan social inteligence yang kokoh. Bahkan dalam teori Murray bahwa no brain no personality, kepribadian sangat dipengaruhi oleh otak. Perasaan, memori yang disadari atau tidak disadari, semua keyakinan, sikap, ketakutan dan nilai. Dengan demikian bila kelas mampu mengasah dan memberikan otak pengalaman baru, keyakinan tentang keindahan damai, seni dalam damai dan keindahan-keindahan akan memberikan stilumus yang baik bagi otak. Bahkan otak mampu melakukan kontrol proses, karena kontrol proses dalam otak adalah sesuatu yang penting bagi otak, apalagi dalam rangka pembentukan kepribadian. Mengamati susunan fungsi otak kita akan terlihat bagaimana pengetahuan diterima oleh otak. Semakin banyak indeks ditulis oleh memori dengannya semakin baik kesempatan untuk mengingatnya dengan apa yang sudah anda tahu. Berikut adalah beberapa pengaruh kritis dalam memori ${ }^{18}$ :

- Keunggulan

- Kedekatan waktu

- Perubahan/keputusan

- Keunikan

- Emosi

- Visual

- Gumpalan informasi

- Aturan internal

- Ulangan/latihan

- Keberagaman pembelajar

- Usia dan ingatan

- Ingatan dan orang lain

- Ingatan jangka pendek dan jangka panjang

- Tidur dan ingatan

Guru sebagai role model dan aktor bina damai di ruang kelas juga harus mempunyai prinsip ini dalam proses pembelajaran. Bahwa prinsip melindungi (in protection) dan prinsip mendampingi (in assistance) adalah kerangka acuan dalam mendidik dan mengarahkan proses pembelajaran.Sehingga dalam setiap pemilihan kata, bahan, gambar, dan ilustrasi harus berpihak pada bagaimana prinsip melindungi dan mendampingi. Sehingga meminjam istilah Bourdieu

$\overline{18}$ Lou Russel, The Accelerated Learning Fieldbook (Bandung: Nusamedia, 2012), hlm. 134. 
bahwa institusi pendidikan juga terlibat dalam membudayakan kesenjagan sosial dapat diminimalisir. Karena mau tidak mau, realita di lapangan pendidikan memang seringkali menjadi agen dalam menanamkan dan membangun kesenjangan sosial. Bila tidak mau dikatakan penopang kesenjangan sosial. ${ }^{19}$

Setiap komunitas memiliki bentuk komunikasi dan interaksi yang berbedabeda,disesuaikan dengan kondisi masyarakat yang ada. pola komunikasi dan interaksi yang terbentuk menentukan bagaimana bentuk masyarakat itu. Khususnya dalam membangun keharmonisan dan kerukunan dalam sebuah masyarakat yang majemuk. Pola komunikasi itu terbentuk dalam ruangruangsosial termasuk kelas dalam sebuah institusi pendidikandan ruang keagamaan. Ruang-ruang sosial tersebut sangat menentukan pola komunikasi sebuah komunitas yang majemuk, karena dalam ruang sosial-budaya yang memungkinkan. Manakala perbedaan individu dapat dipertemukan secara unik dan apik. Komunikasi itu sangat mungkin terjadi dalam komunikasi sosial yang bentuk dan pola harmonis dan konstruktif.

Sebaliknya bila dalam aplikasi dan proses pembelajaran meninggalkan prinsip-prinsip tersebut, tidak mungkin tidak akan bersifat destruktif dan merusak bangunan sosial yang ada di masyarakat. Sekolah pun gagal menjadi agen bina damai yang bersifat soft dan luwes. Karena mengutip Jalaludin Rakhmat ${ }^{20}$ bahwa komunikasi selalu terjadi setiap hari dari bangun tidur hingga tidur lagi, setiap orang selalu melakukan komunikasi khususnya dengan orangorang terdekat dan saling mempengaruhi satu sama lain. Maka Lou Russel menyampaikan dalam bukunya tentang The Accelerated Learning Fieldbook ${ }^{21}$ bahwa hindari kata-kata negatif berikut ini: "seharusnya, harus, jangan, tidak bisa". Kata-kata itu dapat menyebabkan efek pygmalion ${ }^{22}$ yang negatif.

19 Baca lebih dalam kajian kritis dalam Nanang Martono, Kekerasan Simbolik di Sekolah: Sebuah Ide Sosiologi Pendidikan Pierre Bourdieu. Jakarta: Penerbit Grafindo, 2012). Tulisan tersebut memaparkan bagaimana institusi pendidikan ternyata menjadi agen dalam membudayakan kesenjangan sosial melalui kekerasan simboliknya.

20 Op.cit.

21 Lou Russel. The Accelerated..., hlm. 200.

22 Efek Pygmalion berasal dari mitos Yunani tentang seorang pemahat. Konsep ini yang diartikan konsep Bumerang yang menekankan pada apabila Anda memberi kepercayaan pada seseorang maka Anda membuat mereka mampu mencapai apa yang mereka inginkan. 


\section{KESIMPULAN}

Suwardi Endraswara ${ }^{23}$ menuliskan bahwa hidup ini memang belajar. Hidup adalah sebuah pilihan perlu refleksi dan mawas diri. Perlu melakukan restorasi mental dan pikiran bila tidak ingin menjadi korban kehidupan dan perusak kehidupan. Maka mulailah berdamai dengan diri sendiri dan orang lain. Pada akhirnya cinta damai yang Anda miliki akan menjadi kepribadian. Kepribadian yang menurut beberapa teori dipengaruhi oleh apa yang diterima dan diolah otak kita. Maka melahirkan masyarakat cintai damai perlu dimulai pendidikan karena disanalah otak diasah dan dikembangkan. Maka apabila sekolah/madrasah mampu menjadi dan memberikan bina damai melalui ruang-ruang kelas maka akan lahir generasi penerus yang cintai damai.

\section{DAFTAR PUSTAKA}

Endraswara, Soewardi. 2015. Revolusi Mental dalam Budaya Jawa. Jakarta: Narasi. Goleman, Daniel. 2007. Social Inteligence. Jakarta: PT. Gramedia.

Humaisyi, M. Syafiq. 2012. Pengantar IPS. Ponorogo: STAIN Press.

Mahfud. 2011. Pendidikan Multikultural. Yogyakarta: Pustaka Pelajar.

Mantu, Rahman. 2015. "Bina Damai dalam Komunitas Pesantren: Sebuah Upaya Counter-Radikalisme" dalam Jurnal Walisongo, Volume 23, Nomor 1.

Martono, Nanang. 2012, Kekerasan Simbolik di Sekolah: Sebuah Ide Sosiologi Pendidikan Pierre Bourdieu. Jakarta: Penerbit Grafindo.

Nurhidayah. 2014. "Dekonstruksi Fanatisme Keagamaan Berbasis Sekolah: Alternatif Pendekatan Deradikalisasi Gerakan Keagamaan di Tingkat Usia Pelajar Muslim" dalam Jurnal An-Nidzam. Vol. 1, No. 2.

Nurhidayah. 2017. Kematangan Psikologis Sebagai Dampak Proses Pembelajaran Tahun 2016-2017. Penelitian. Tidak diterbitkan.

Pedak, Mustamir. 2009. Metode Supernol Menaklukan Stress. Jakarta: Hikmah. Rahmatullah, Azzam Syukur. 2014. "Attachment Parenting dalam Perspektif Psikologi Pendidikan Islam" dalam Jurnal An-Nidzam, Vol 1, No 2.

$\overline{23}$ Dalam Soewardi Endraswara, Revolusi Mental dalam Budaya Jawa. (Jakarta: Narasi, 2015). 
Russel. Lou. 2012. The Accelerated Learning Fieldbook. Bandung: Nusamedia.

Www. Peace -generation.org. 10 Tahun Peace Generation. Diunduh tanggal 10 Januari 2018. 